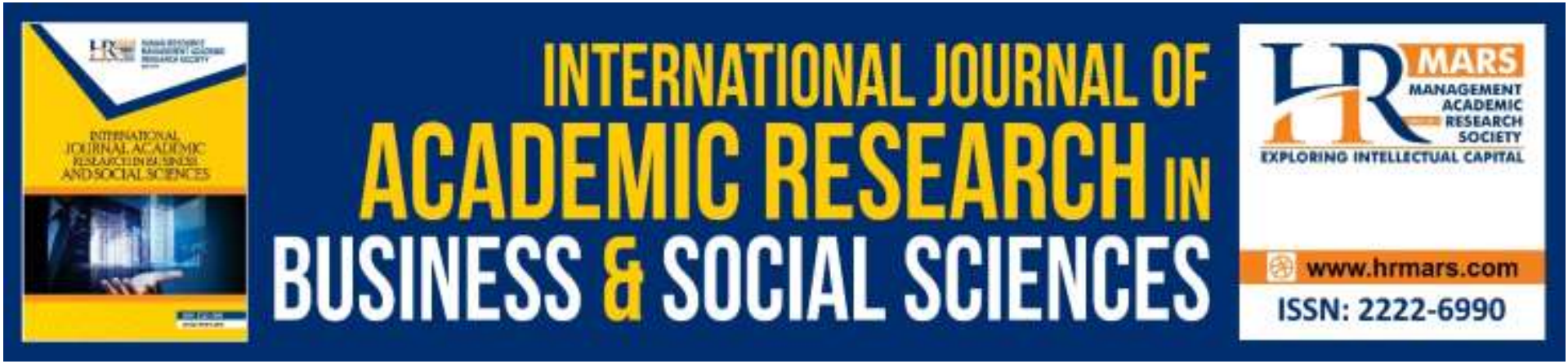

\title{
The Determinants of Organizational Citizenship Behaviour (OCB)
}

Noor Rafhati Romaiha, Fatin Syahirah Faizul Maulud, Wan Musyirah Wan Ismail, Arnida Jahya, Nurul Fahana, Aini Harun

To Link this Article: http://dx.doi.org/10.6007/IJARBSS/v9-i8/6222

DOI: $10.6007 /$ IJARBSS/v9-i8/6222

Received: 17 May 2019, Revised: 28 June 2019, Accepted: 03 August 2019

Published Online: 22 August 2019

In-Text Citation: (Romaiha et al., 2019)

To Cite this Article: Romaiha, N. R., Maulud, F. S. F., Ismail, W. M. W., Jahya, A., Fahana, N., \& Harun, A. (2019). The Determinants of Organizational Citizenship Behaviour (OCB). International Journal of Academic Research in Business and Social Sciences, 9(8), 124-133.

Copyright: () 2019 The Author(s)

Published by Human Resource Management Academic Research Society (www.hrmars.com) This article is published under the Creative Commons Attribution (CC BY 4.0) license. Anyone may reproduce, distribute, translate and create derivative works of this article (for both commercial and non-commercial purposes), subject to full attribution to the original publication and authors. The full terms of this license may be seen at: http://creativecommons.org/licences/by/4.0/legalcode

\section{Vol. 9, No. 8, 2019, Pg. 124 - 133}

Full Terms \& Conditions of access and use can be found at http://hrmars.com/index.php/pages/detail/publication-ethics 


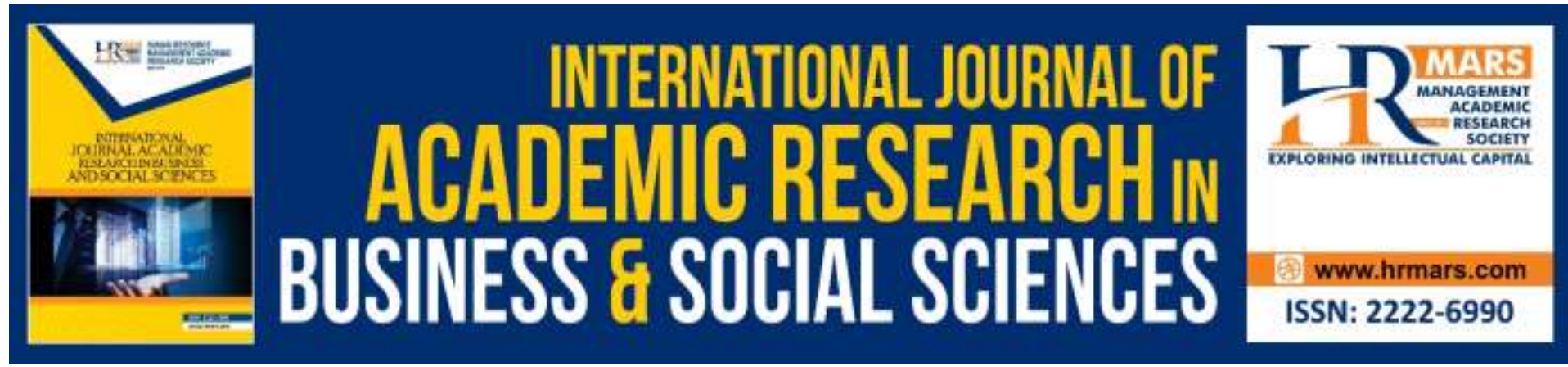

\title{
The Determinants of Organizational Citizenship Behaviour (OCB)
}

\author{
Noor Rafhati Romaiha, Fatin Syahirah Faizul Maulud, Wan \\ Musyirah Wan Ismail, Arnida Jahya, Nurul Fahana \\ Faculty of Business and Management, Universiti Teknologi MARA Melaka
}

\author{
Aini Harun \\ Faculty of Business and Management, Universiti Teknologi MARA Sarawak \\ Email: noorrafhati@uitm.edu.my
}

\begin{abstract}
Organizational Citizenship Behavior (OCB) has always been a major concern in the organizational behaviour field. Albeit OCB has existed since decades ago, it is still in the emerging of development. Hence, this study intended to investigate the determinants of OCBs which comprising altruism, conscientiousness, civic virtue, sportsmanship and courtesy. It was conducted at Agency Kaunseling \& Pengurusan Kredit (AKPK) and the data were collected from 113 respondents by using self-administered questionnaires. The obtained results from correlational analysis proved that all independent variables have positive relationship with the dependent variables. However, multiple regression analysis revealed only altruism, sportsmanship and courtesy are significant whereas the other two are found to be insignificant.
\end{abstract}

Keywords: Organizational Citizenship Behaviour, Altruism, Conscientiousness, Civic Virtue, Sportsmanship and Courtesy

\section{Introduction}

Organizational Citizenship Behavior (OCB) has always been a major concern in the field of organizational behavior (Ramezani, Roohazad, Alizadeh \& Amiri, 2015). Nowadays, productivity and profitability of an organization is still depending on human resources, despite the reliant on modern machinery and equipment (Abdullah Osman et al., 2015). Obviously employee commitments are imperative for the formation of competitive advantage, however it is difficult to be achieved due to vulnerability within the organizational environment (Hart, Gilstrap, \& Bolino, 2016). Therefore, for the purpose of international trade and competition, OCB have been proven to be useful for both employees and employers at the workplace (Bergeron, Shipp, Rosen \& Furst, 2013). According to Markoczy and Xin (2004), organization cannot survive well if the workforce does not practice positive behaviors that pertinent to the organization's requirement. Hence, in order to accomplish high-performance goals which 
leads to organizational success, developing positive organizational behavior and work environment is vital (Zayas-Ortiz, Rosario, Marquez \& Gruñeiro, 2015).

Unfortunately, developing OCB in the organization is not easy due to employees are unaware of its importance, thinking those kinds of behaviors are not significant particularly in improving their performance. Due to this, they are more likely to involve in undesirable and negative behaviors while at the workplace (Islam, Akter \& Lecturer, 2015). Absenteeism, theft, taking excessive breaks, misconduct, being uncooperative with others and such are some of the main examples of those behaviors mentioned. Therefore, organization is emphasized on practicing $O C B$ in order to reduce and overcome these negative and undesirable traits from occurred. Changing these employees' attitudes and behaviors will aid in organizational development (Lee, Kim \& Kim, 2013). Thus, the success of the organization is depending on employees' willingness to perform tasks beyond their job requirements and be a good servant for the organization that they are working for (Markoczy and Xin 2004).

Thus, this study aims to identify the factors that are significant and correlate with OCB at Agensi Kaunseling \& Pengurusan Kredit (AKPK) headquarter located at Kuala Lumpur, Malaysia. It can be a great use to this organization itself to further enhance its effectiveness and success in the future.

\section{Literature Review}

\section{Organizational Citizenship Behaviour (OCB)}

Past definition by Organ (1988) stated that OCB is a voluntary behaviour acted by the employees, even though it was not directly required by the organization and not formally administered by the reward system. This action indicates that these employees are being noble and capable of doing work that exceeded or beyond their minimum requirements in job descriptions. Alternatively, OCB can also best be describe as extra-role behaviours of the employees who performs task exceed their job scope. Hence, OCB is a behaviour where it does not have a mandatory obligation and is depends on the choice of employees. Therefore, the employee who owned the OCB traits is capable in showing behaviours beyond the routine roles, job descriptions and obligations without any expectation on receiving highly rewards or recognition but more prefer to contribute for the good welfare of the organization. This statement can be supported by Korkmaz and Arpacı (2009) where the authors mentioned that the OCB came from extraordinary efforts of employees, with intention of gaining success to the organization.

\section{Altruism}

This dimension refers to a selfless behaviour of people where they are concern for other individuals' welfare and rights, be more empathy and do things that will give benefits to others (Khan et al., 2017). Originally defined by Organ (1988) as a discretionary behavior to help other colleagues in accomplishing tasks and solving work-related problems. In other words, altruism is behaviours that directly aimed at helping a specific person and emphasized on motivates their co-workers either in doing their work or when they are having problems. By practising this behaviour, it leads to increase individual's performance as well as group efficiency (Sharma \& Jain, 2014). Apart from that, as cited by Yen and Neihoff (2004), altruism will aid in teamwork and cooperation, thus further giving chance to the employees in improving their own knowledge. Therefore, it is proven that altruism is an important 
determinant of OCB (Muthuraman and Al-Haziazi, 2017). As a result, this study hypothesized that altruism $(\mathrm{H} 1)$ will be positively associated with OCB.

\section{Sportsmanship}

Sportsmanship refers to participants' actions when dealing with unexpected inconveniences that happens in the organization without having any complaint and yet, still doing their best (Ehtiyar, Akta \& Ömüri, 2010). This type of employees usually spend time accomplish their work without complaints and whines (Sharma \& Jain, 2014). Another view from Nielson et al. (2014), the employees want to be more tolerant, do not work excessively and positive when dealing with work issues which means, they will not easily complain when the problems arise at the workplace. Öztürk (2010) also defined this factor as demonstrations of positive attitude and loyalty towards the company, without paying attention to the negative aspects. Podsakoff and Mackenzie (1997) stated that sportsmanship can increase work group morale and effecting in reducing turnover rate. Refraining from spreading gossips and rumours in the office is one example of sportsmanship. Youssef and Luthans (2007) stated that employees with high future focus tend to think about future improvements, thus they are less likely to complain about present matters. They also perceive everything in a bigger picture, resulting in less likely to overreact to negativity. Therefore, it can be hypothesized that sportsmanship will have a positive relationship with $\mathrm{OCB}(\mathrm{H} 2)$.

\section{Conscientiousness}

Sharma and Jain (2014) cited conscientiousness as spending adequate amount of time and effort that go beyond their formal job descriptions for the sake of individuals and group's efficiency. According to Organ (1988), conscientiousness is associated with behaviors of the employees such as punctuality, maintaining work attendance and following rules. They considered themselves as a part of the organization and hence, they know their limitations and responsibilities. Moreover, they are practising a discretionary behavior in the form of adhering to rules and regulations of the organization, even without supervisory from authority or colleagues (Redman \& Snape, 2005). Those who possess this trait will work extra hours, complete task before the dateline and avoid extended unnecessary break (Ehtiyar et al., 2010). A previous research by Yen and Niehoff (2004) revealed that this employee will stay informed and updated with current knowledge about products or services offered. Consequently, conscientiousness aids in giving direction to produce targeted and desired behavior in the organization, thus this determinant is considered important for OCB (King et al., 2005). Accordingly, the third hypothesis (H3) was formulated as "conscientiousness has a significant relationship with $O \mathrm{CB}^{\prime \prime}$.

\section{Civic Virtue}

Organ (1988) defines civic virtue as endorsing and supporting organizational policies as well as participates in its activities. This dimension indicates that the employees are responsibly involve and support the strategies, voluntarily become committees or attending function organized by the organization (Sharma \& Jain, 2014). These participants are really concern with the image and reputation of the organization (Redman \& Snape, 2005). They can be considered to have high level of interest and loyalty towards the organization (Polat, 2009). Nielson, Bachrach, Sundstrom and Halfhill (2014) highlight, this behaviour usually includes offering positive criticism or suggesting solutions to problems. Attending non-mandatory 
meetings and keeping track with the current events in the organization are some examples of this behaviour (Organ, 1988). Finally, high level of civic virtue will take interest in activities that help to foster the organization's image. Therefore, civic virtue is found to has significant contribution in determining OCBs (Jacqueline, Shapiro, Kessler \& Purcell, 2004). In view of that, $\mathrm{H} 4$ was develop as "civic virtue has a positive correlation with OCBs".

\section{Courtesy}

Courtesy is considered as avoiding problems from occurs and taking required actions to reduce the impact of the problems in the future (Muthuraman and Al-Haziazi, 2017). Shanker (2016) also highlighted courtesy as a type of behaviour where the employees notify their colleagues about changes that may directly or indirectly affect their work thus, aids them in better preparing for future problems that may arise. This is directed towards participants giving advance notices, timely reminders and suitable information when needed are some examples of courtesy (Sharma \& Jain, 2014). Podsakoff, Mackenzie, Paine and Bachrach (2000) mentioned employees who implemented courtesy are having less intergroup conflict and time to deal with conflict management activities. Nevertheless, the employees with high courtesy will always show behavior will prevent them from creating problems, thus with more mindful and cautious in engaging with any actions that can affecting their co-workers. Lastly, according to Dimitriades (2007), courtesy also contributes to OCB because it helps to avoid relationship problems at the workplace. Consequently, the present study hypothesized that courtesy $(\mathrm{H} 5)$ is positively related with OCB.

\section{Research Methodology}

This study was conducted at AKPK headquarter in Kuala Lumpur, Malaysia and the population of interest covered overall 164 employees who are currently working at this organization. Thus, for the purpose of gathering information, 113 respondents were conveniently selected to participate in this study. Consequently, according to Sekaran and Bougie (2013), convenience sampling technique is the best method to gather information from members of the population who are conveniently available to provide it in a quick and efficient. Hence, responses were obtained through self-administered questionnaire which consists of 7 sections including Demographic Information, OCB, Altruism, Civic Virtue, Conscientiousness, Sportsmanship and Courtesy. This questionnaire was adopted from the past journals cited from Ozturk (2010) and Muthuraman and Al-Haziazi (2017). A Likert Scale ranging from 1 (strongly disagree) until 5 (strongly agree) were used to measure each sections of the questionnaire. Hence, the Statistical Package for Social Sciences was used to analyse the data. 


\section{Findings}

\section{Reliability Analysis}

Table 1

Reliability Analysis Results

\begin{tabular}{lcc}
\hline \multicolumn{1}{c}{ Variables } & $\begin{array}{c}\text { Cronbach's } \\
\text { Alpha }\end{array}$ & Number of Items \\
\hline Organizational Citizenship Behaviors & 0.653 & 5 \\
Altruism & 0.861 & 6 \\
Conscientiousness & 0.778 & 6 \\
Sportsmanship & 0.829 & 6 \\
Civic Virtue & 0.844 & 6 \\
Courtesy & 0.813 & 6 \\
\hline
\end{tabular}

Table 1 shows the Cronbach's Alpha coefficient value for all sections in this study. The reliability result for OCB is 0.653 which is considered as moderate. Meanwhile, the Cronbach alpha values for other variables are more than 0.7 and it is found to be reliable since overall results are above 0.7 . Therefore, all items develop have successfully measured the proposed concepts and the outcome was considered moderate, good and very good.

\section{Correlation Coefficient Analysis}

Table 2

Correlation Coefficient Table

\begin{tabular}{lccc}
\hline & $\begin{array}{c}\text { Pearson } \\
\text { Correlation }\end{array}$ & $\begin{array}{c}\text { Sig. } \\
\text { (2-tailed) }\end{array}$ & $\mathrm{N}$ \\
\hline Altruism & $0.594^{* *}$ & 0.000 & 113 \\
Conscientiousness & $0.455^{* *}$ & 0.000 & 113 \\
Sportsmanship & $0.618^{* *}$ & 0.000 & 113 \\
Civic Virtue & $0.454^{* *}$ & 0.000 & 113 \\
Courtesy & $0.650^{* *}$ & 0.000 & 113 \\
$* *$ Correlation is significant at the 0.01 level (2-tailed). & & \\
\hline
\end{tabular}

Table 2 illustrates the results of correlations analysis for all independent variables toward dependent variable. Based on the above result, there was a significant, positive and moderate correlation between all independent variables (altruism, sportsmanship, conscientiousness, civic virtue, courtesy) and OCB since the Pearson's correlation coefficient results is within the range of 0.41 and 0.70 (Guilford, 1973). 


\section{Multiple Regression Analysis}

Table 3

Coefficient of Multiple Regression Analysis

\begin{tabular}{lcccc}
\hline & $\begin{array}{c}\text { Unstandardized } \\
\text { Coefficients } \\
\text { (Beta) }\end{array}$ & $\begin{array}{c}\text { Standardized } \\
\text { Coefficients } \\
\text { (Beta) }\end{array}$ & T & Sig. \\
\hline Altruism & .234 & .262 & 2.186 & .031 \\
Conscientiousness & -.143 & -.147 & -1.359 & .177 \\
Sportsmanship & .221 & .245 & 2.072 & .041 \\
Civic Virtue & -.042 & -.042 & -.403 & .688 \\
Courtesy & 417 & .420 & 3.719 & .000 \\
R = 0.703 & & & & \\
R square $=0.494$ & & & & \\
Adjusted R Square $=0.471$ & & & & \\
Std. Error of The Estimate $=0.39765$ & & & & \\
Dependent Variable = Organizational Citizenship Behavior & & & \\
\hline
\end{tabular}

Table 3 shows finding for coefficient of Multiple Regression Analysis. Overall results revealed that three out of five variables are significant towards OCB $(P<0.05)$. These include altruism $(\beta=0.262, p<0.05)$, sportsmanship $(\beta=0.245, p<0.05)$ and courtesy $(\beta=0.420, p<0.05)$. Meanwhile, the other two which are conscientiousness and civic virtue are considered insignificant because their P-value are more than 0.05. Moreover, this table will also answer the second objective of this study, which is "to identify the most influential determinant of OCBs in AKPK". Hence, the finding discovered that courtesy is the most significant factor influencing OCBs in AKPK with the highest Beta value $(\beta=0.420)$ at the significance value of $0.000(p<005)$.

\section{Conclusion}

From the result of analysis, it was found that three out of five independent variables which are altruism, sportsmanship and courtesy were having significant and positive relationships with OCBs. Secondly, it was empirically found that courtesy was the most dominant predictor among other variables. The first hypothesis reveals a significant relationship between the first predictor, altruism with OCBs. The result indicates that the P-value 0.031 and thus, $\mathrm{H} 1$ is accepted. This finding was supported by previous scholar, Islam et al. (2015) who found out that altruistic is indeed one of benefactor to the organization. However, for the second independent variable which is conscientiousness, the $\mathrm{H} 2$ was rejected because the result shown insignificant relationship since the P-value exceeds 0.05. Bertolino, Truxillo and Fraccaroli (2013) once clarify, older employees are highly likely to exhibit conscientiousness compared to younger employees. The result of conscientiousness can be explained by most participants of this study are between 20 to 29 years old (36.3\%) and 30 to 39 years old $(39.8 \%)$ which considered as young. Thus, based on this study, conscientiousness has no impact on OCBs at AKPK.

Next, it was found that there is a significant relationship between sportsmanship and OCB, similar with the study conducted by Muthuraman and Al-Haziazi (2017). Thus, H3 is supported. Moreover, the result for the fourth hypothesis demonstrates insignificant 
relationship between civic virtue and OCBs. Based on previous research by Kang and Ryan (2016), older or senior employees are highly likely to exhibit civic virtue compared to young employees. Again, based on the frequency analysis, older or senior employees that are above 50 years old only contributed around 8 out of 113 respondents in this study. Consequently, it strengthens the result found which is civic virtue has no influence towards OCB. Hence, H4 was rejected. Finally, for the last variable, it was found that there is a relationship between courtesy and OCBs. Obviously, the employees are concerned towards the progress of organization by engaging in activities that will help in organizational development (Islam et al., 2015) Therefore, H5 is accepted.

Therefore, based on the above findings, employers should pay more attention towards these three variables which are altruism, sportsmanship and courtesy. The top management should take extra initiative in encouraging the employees to exhibit OCB at the workplace (Muthuraman and Al-Haziazi (2017). This is because, a friendly atmosphere can be developed when both managers and subordinates are able to create cooperation and understanding among them which leads to a positive working environment (Dehghani, Hayat, Kojuri \& Esmi 2013). Thus, it's not only aids to improve the employees' performance as well as achieving organizational goal, but also aids in avoiding conflicts in the long run.

\section{References}

Osman, A. Othman, Y. H. S. M., Rana, S., Solaiman, M., \& Lal, B. (2015). The influence of job satisfaction, job motivation \& perceived organizational support towards organizational citizenship behavior (OCB): A perspective of American-based organization in Kulim, Malaysia. Asian Social Science, 11(21), 174. doi:10.5539/ass.v11n21p174

Youssef, A. C. M., \& Luthans, F. (2007). Positive organizational behavior in the workplace: The impact of hope, optimism, and resilience. Journal of Management, 33(5), 774-800. http://doi.org/10.1177/0149206307305562

Bergeron, D. M., Shipp, A. J., Rosen, B., \& Furst, S. A. (2013). Organizational citizenship behavior and career outcomes. The cost of being a good citizen. Journal of Management, 39(4),958-984.

Bertolino, M., Truxillo, D. M., \& Fraccaroli, F. (2013). Age effects on perceived personality and job performance. Journal of Managerial Psychology, 28(7-8), 867-885.

Dehghani, M. R., Hayat, A. A., Kojuri, J., \& Esmi, K. (2015). Role of organizational citizenship behavior in promoting knowledge sharing. Journal of Health Management and Informatics, 2(4), 126-131.

Dimitriades, Zoe. (2007). The influence of service climate and job involvement on customeroriented organizational citizenship behavior in Greek service 54 organizations: A survey. Employee Relations. 29. 469-491. 10.1108/01425450710776290.

Ehtiyar, V. R., Akta, A., \& Ömüri, E. (2010). The role of organizational citizenship behavior on university student's academic success. Tourism and Hospitality Management, 16(1), 47-61.

Falvo, R., Hichy, Z., Capozza, D., De Carlo, N.A. (2002), Organizational commitment, personal and collective self-efficacy, and organizational behaviors. TPM-Testing, Psicometria, Metodologia, 9(1-2), 57-70.

Guildford, J. P. (1973). Fundamental statistics in psychology and education, $5^{\text {th }}$ Edition. New York: McGraw Hill. 
Hart, T. A., Gilstrap, J. B. \& Bolino, M. C. (2016), Organizational citizenship behavior and the enhancement of absorptive capacity. Journal of Business Research, Elsevier, vol. 69(10), pages 3981-3988.

Islam, M. S., Akter, S., \& Lecturer, F. A. (2015). Factor affecting organizational citizenship behaviour of corporate sector in Bangladesh. European Journal of Business and Management, 7(31), 2222-2839.

Jacqueline, A. M., Shapiro, C., Kessler, I., and Purcell, J. (2004). Exploring organizationally directed citizenship behavior: Reciprocity or 'it's my job'?. Journal of Management Studies, 41:1, 0022-2380. Jahangir 2004

Kang, Y. H., \& Ryan, A. M. (2016). Should more senior workers be better citizens? Expectations of helping and civic virtue related to seniority. SpringerPlus, 1-12. http://doi.org/10.1186/s40064-016-3097-1

Khan, S. K., Feng, C. F., Tunku, U., Rahman, A., Chong, M., Zhen, W.M. (2015). The factors affecting organization citizenship behavior: A study in the fitness industry. International Journal of Recent Advances in Organizational Behaviour and Decision Sciences (IJRAOB) An Online International Research Journal, 1(2), 2311-3197.

King, E., George, J., \& Hebl, M. (2005). Linking personality to helping behaviors at work: An interactional perspective. Journal of Personality. Blackwell Publishing, Vol. 73, No. 3.

Korkmaz, T., \& Arpaci, E. (2009). Relationship of organizational citizenship behavior with emotional intelligence. Procedia - Social and Behavioral Sciences, 1(1), 2432-2435. http://doi.org/10.1016/j.sbspro.2009.01.428

Lee, U. H., Kim, H. K. \& Kim Y. H. (2013). Determinants of organizational citizenship behavior and its outcomes. Global Business and Management Research: An International Journal. 5(1): 54-65.

Mahlangu, B. P., \& Kruger, L. (2015). The Impact of the Maintenance Management System: A Case Study of the Petrosa Gtl Refinery. The South African Journal of Industrial Engineering, 26(3), 167-182. http://doi.org/10.7166/26-3-1197

Markoczy, L., \& Xin, K. (2004). The Virtues of Omission in Organizational Citizenship Behavior. University of California, 1-29. Retrieved from http://www.goldmark.org/livia/

Muthuraman, S., \& Al-Haziazi, M. (2017). Examining the Factors of Organizational Citizenship Behavior with Reference to Corporate Sectors in Sultanate of Oman. International Review of Management and Marketing, 2017, 7(1), 413-422.

Nielson, T. M., Bachrach, D. G., Sundstrom, E., \& Halfhill, T. R. (2010). Utility of OCB Organizational Citizenship Behavior and Group Performance in a Resource Allocation Framework. Journal of Management, 38(2), 668-694

Organ, D. W. (1988). Organizational citizenship behavior: The good soldier syndrome. $1^{\text {st }}$ ed. Lexington, Massachusetts/Toronto: D.C. Heath and Co.

Öztürk, F. (2010). Determinant of organizational citizenship behavior among knowledge workers: The role of job characteristics, job satisfaction, and organizational commitment. Dissertation, (August), 1-161.

Podsakoff, P. M., \& Mackenzie, S. B. (1997). The impact of organizational citizenship behavior in Organizational performance: review and suggestion for future research, Human Performance, 10, 133-51

Podsakoff, P. M., Mackenzie, S. B., Paine, J. B., Bachrach, D. G. (2000). Organizational citizenship behaviors: A critical review of the theoretical and empirical literature and suggestions for future research. Journal of Management, 26(3): 513-563. 
Ramezani, S., Roohazad, A., Alizadeh, Z., \& Amiri, S. R. (2015). Identification and ranking of the factors affecting the development of organizational citizenship behavior a case study of national Iranian oil products. International Journal of Economics, Commerce and Management, III (5), 1138-1154.

Redman, T., \& Snape, E. (2005). I to Wed: The role of consciousness transformation in compassion and Altruism. Journal of Management Studies, 42(2), 2200-2380.

Sekaran, U., \& Bougie, R. (2013). Research Methods for Business: A Skill Building Approach. John Wiley \& Sons.

Shanker, M. (1988). Organizational citizenship behavior dimensions in Indian companies. International Conference on Multidisciplinary Research \& Practice, I (7), 25-28.

Sharma, V., \& Jain, S. (2014). A Scale for Measuring Organizational Citizenship Behavior in Manufacturing Sector. Pacific Business Review International, 6(8), 57-62.

Polat, S. (2009), Organizational citizenship behavior (OCB) display levels of the teachers at secondary schools according to the perceptions of school administrators. Procedia Social and Behavioral Sciences, 1, 1591-1596.

Yen, H. R., \& Niehoff, B. P. (2004). Organizational Citizenship Behaviors and Organizational Effectiveness: Examining Relationships in Taiwanese Banks. Journal of Applied Social Psychology, 34 (8), 1617-1637.

Zayas-Ortiz, M., Rosario, E., Marquez, E. \& Gruñeiro, P. (2015). Relationship between organizational commitments and organizational citizenship behavior in a sample of private banking employees. International Journal of Sociology and Social Policy, 35(1/2), 91-106. http://dx.doi.org/10.1108/IJSSP-02-2014-0010 